喉頭蓋の倒れ込みにより呼吸障害を生じた 2 症例

\author{
田中 明子・土師 知行・新正由起子 \\ 前田 秀明・竹林 慎治・八木 伸也
}

\title{
Inspiratory Dyspnea Caused by an Epiglottal Prolapse
}

\author{
Akiko Tanaka, Tomoyuki Haji, Yukiko Shinjo, \\ Hideaki Maeda, Shinji Takebayashi and Nobuya Yagi \\ (Kurashiki Central Hospital)
}

\begin{abstract}
We report 2 adult cases of inspiratory dyspnea caused by an epiglottal prolapse.
The first case was a 61-year-old man who was suffering from inspiratory dyspnea, especially while sleeping. A laryngofiberscopic examination revealed that the epiglottis was contacting the posterior pharyngeal wall during inspiration, causing airway obstruction. A partial epiglottectomy with a Holmium : YAG laser improved respiratory dystress during sleep.

The second case was a 60 -year-old man who also suffered from dyspnea while sleeping. The laryngofiberscopic findings were the same as in the first case, and a partial epiglottectomy was also effectve for the dyspnea during sleep. A pathological examination revealed degeneration of the epiglottic cartilage
\end{abstract}

The Holmiun : YAG laser was useful in resecting the epiglottic cartilage in both cases.

Key words : inspiratory dyspnea, epiglottal prolapse, airway obstruction, partial epiglottectomy, Holmiun : YAG laser

はじめに

喉頭蓋の倒れ込みが気道狭窄を起こして生じる吸気性 呼吸障害は，喉頭軟化症など乳児では比較的よくみられ るが，成人ではまれである.今回われわれは，喉頭蓋の 倒れ込みにより吸気性呼吸障害を生じた成人 2 例を経験 し，手術加療を行ったので報告する.

\section{症例}

症例 $1: 61$ 歳, 男性.

主訴：咽頭違和感, 吸気時呼吸困難.

既往歴 : 糖尿病.

家族歴：特記すべさことなし。

現病歷 : 平成 7 年頃から咽頭違和感を自覚していたが, 平成 8 年 1 月頃より, 吸気時に呼吸困難を生じるように
なった，呼吸困難は仰臥位になると増強するため，睡眠 時は側臥位をとっていた．次第に軽度の曣下困難柿よび 構音障害を自覚するようになったため, 当院神経内科を 受診し平成 8 年 7 月入院精査を受けた。精査の結果, 運 動ニューロン疾患が疑われた. 当科へは, 平成 8 年 7 月 15日上気道の精查目的で紹介された。

初診時所見：喉頭ファイバースュープ検査で，喉頭蓋 が通常より長く, 吸気時に咽頭後壁側に倒れ込及気道を 狭窄するのが観察され(図 1), 呼吸障害の原因と考兄ら れた。喉頭 CR 側面像でも喉頭蓋が倒れ込み，咽頭後壁 側に近接して気道を狭窄している所見を認めた（図 2 ). これは特に仰臥位で著明であった，反回神経麻痺は認め なかった。 また萛腔・咽頭に異常所見はなく, 甲状腺エ コー, 食道透視検查も異常はみられなかった。 


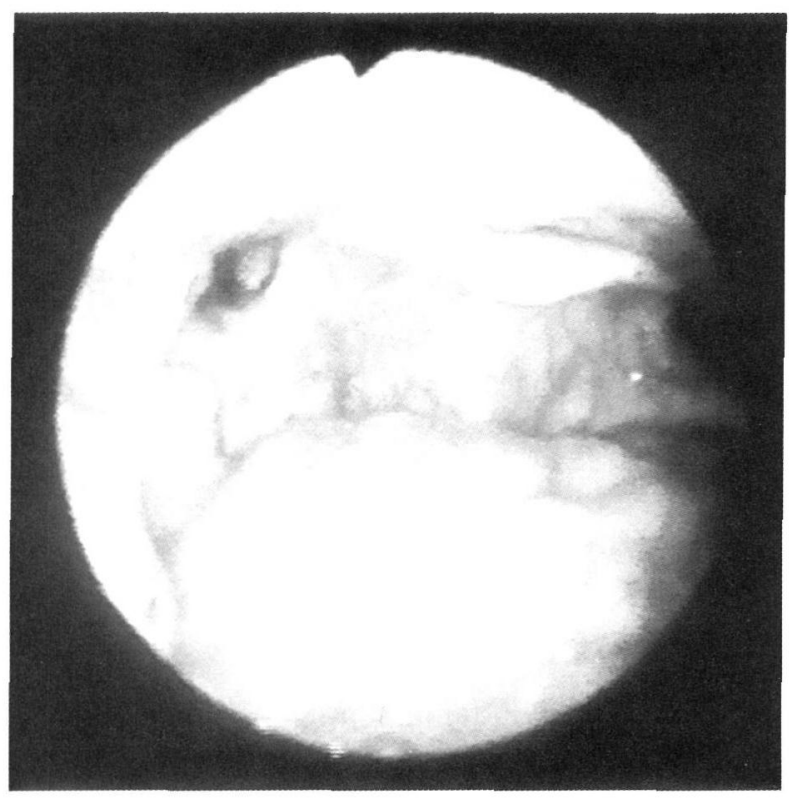

図 1 症例 1 初診時喉頭ファイベースコープ所見

手術扒よび経過: 平成 8 年 9 月 13 日全身麻酔下, ラリ ンゴマイクロサージェリーによる喉頭蓋部分切除術を施 行した。経口挿管後直達喉頭鏡を浅めに挿入し, 喉頭蓋

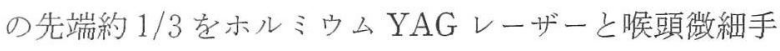
術用の箭刀を用いて切除した。摘出した喉頭蓋軟骨に病 理組織学的な異常はみられなかった。術中写真を図 3 に, 摘出した喉頭蓋軟骨を図 4 亿示与。

手術後, 咽頭違和感亡呼吸困難は消失し, 仰臥位でも 睡眠可能となった。術後 1 力月の喉頭 $\mathrm{CR}$ 側面像を図 5 に示す．喉頭蓋と咽頭後壁との間に十分なスペースが認 められている. また術後 2 カ月の喉頭フ、イバースコー プ所見を図 6 に示す. 吸気時の喉頭蓋の咽頭後壁への倒 れ込みはなくなり気道の狭窄はみられない, 術前より運 動ニューロン疾患による軽度の與下困難感があったが，

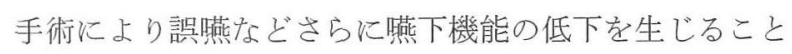
はなかった。

当科と併行して神経内科でも経過観察执よび精查が続 汁られ, 臨床経過と筋電図などの神経学的所見から, 最 終的には進行性筋萎縮性側索硬化症と診断された。

症例 $2: 60$ 歳, 男性.

主訴：咽頭違和感, 睡眠時の呼吸困難.

既往歷：胃潰瘍, 前立腺癌.

家族歴：特記すべきことなし。

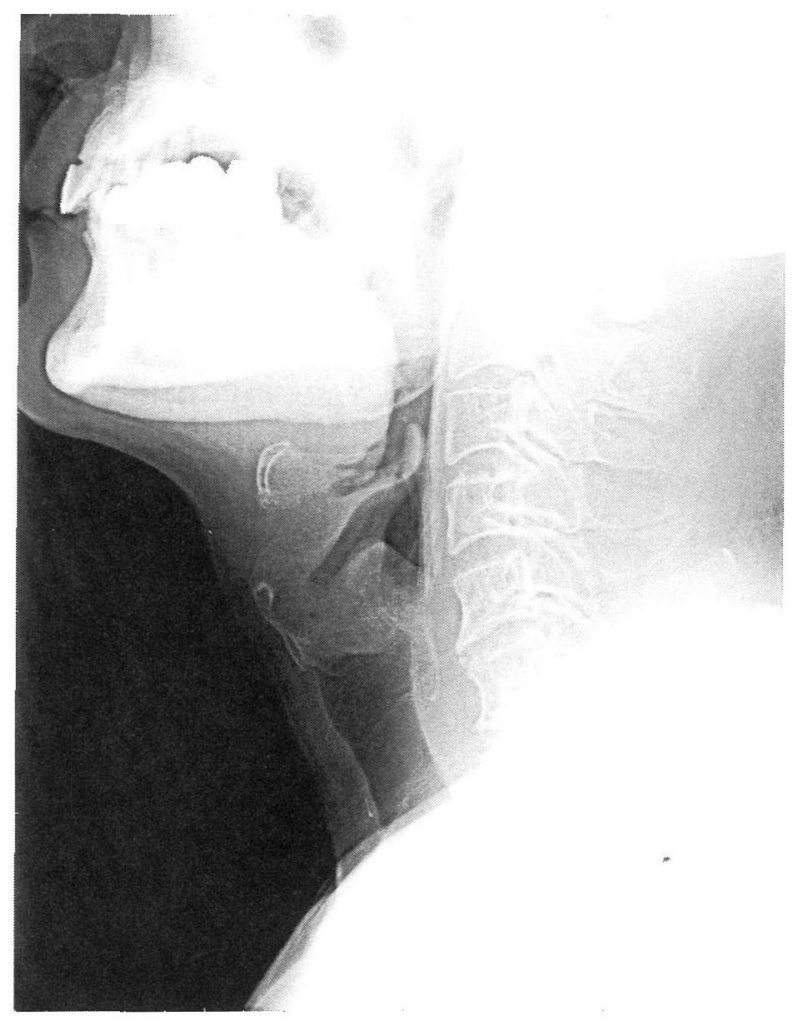

図 2 症例 1 初診時喉頭 CR 側面像

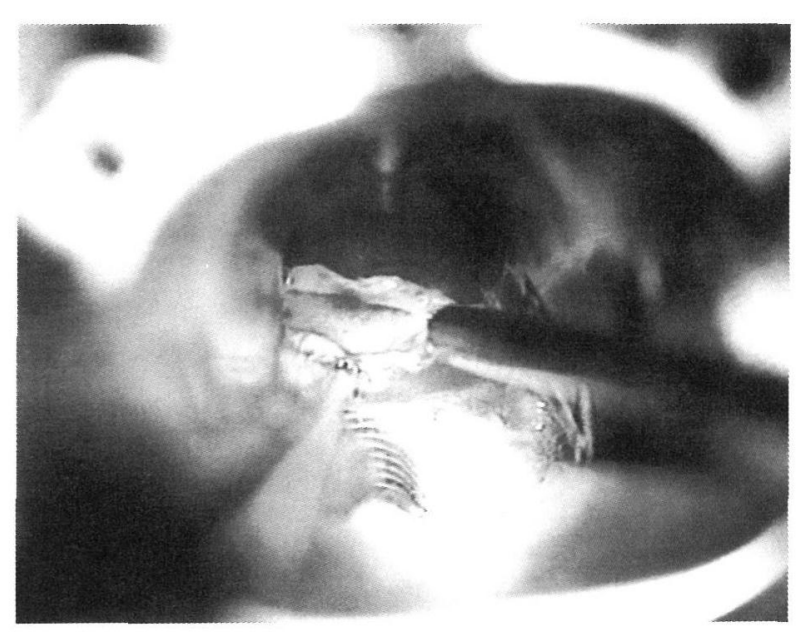

図 3 症例 1 術中写真

ホルミウム YAGレーザーを用いて喉頭蓋軟骨を部分切 除.

現病歴: 平成 7 年夏頃より咽頭違和感を自覚していた。 咽頭違和感は次第に増強し,ささらに睡眠時仰臥位になっ たとき呼吸困難感を自覚するよらになったため, 平成 8 


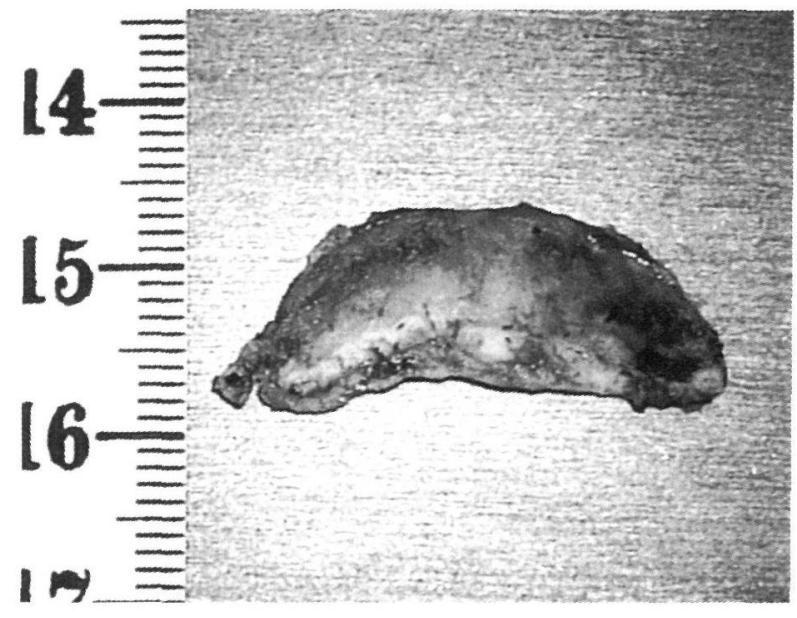

図 4 症例 1 切除した喉頭蓋軟骨

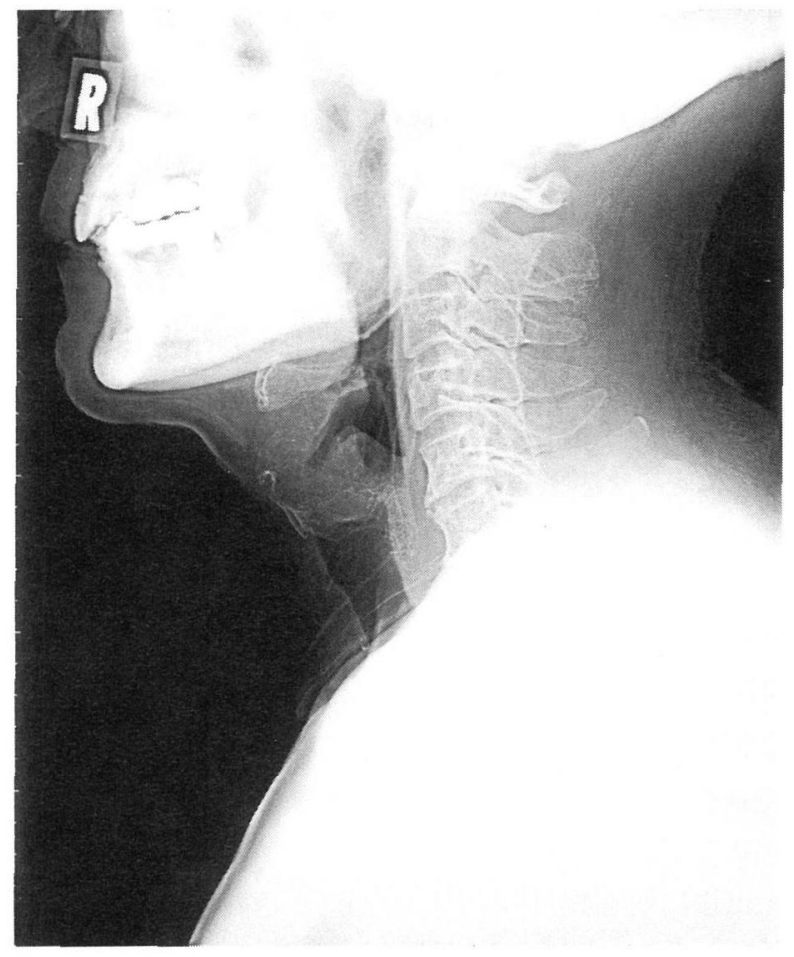

図 5 症例 1 術後 1 力月の喉頭 CR 側面像

年12月25日当科を受診した。

初䛦時所見: 鼻腔・咽頭に異常所見は認めなかった。 症例 1 と同様に，喉頭ファイバースコープ検查で，喉頭 蓋が通常上り長く, 吸気時に咽頭後壁側に倒れ込2, 気 道を狭窄するのが観察され，これは仰臥位で著明であっ

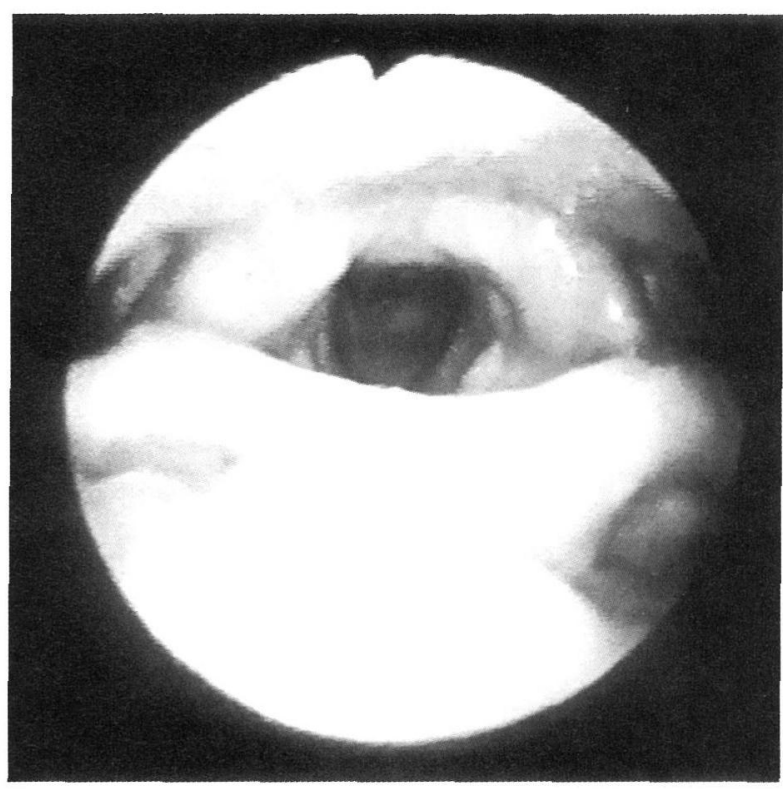

図 6 症例 1 術後 2 カ月の喉頭ファイバースコープ所見

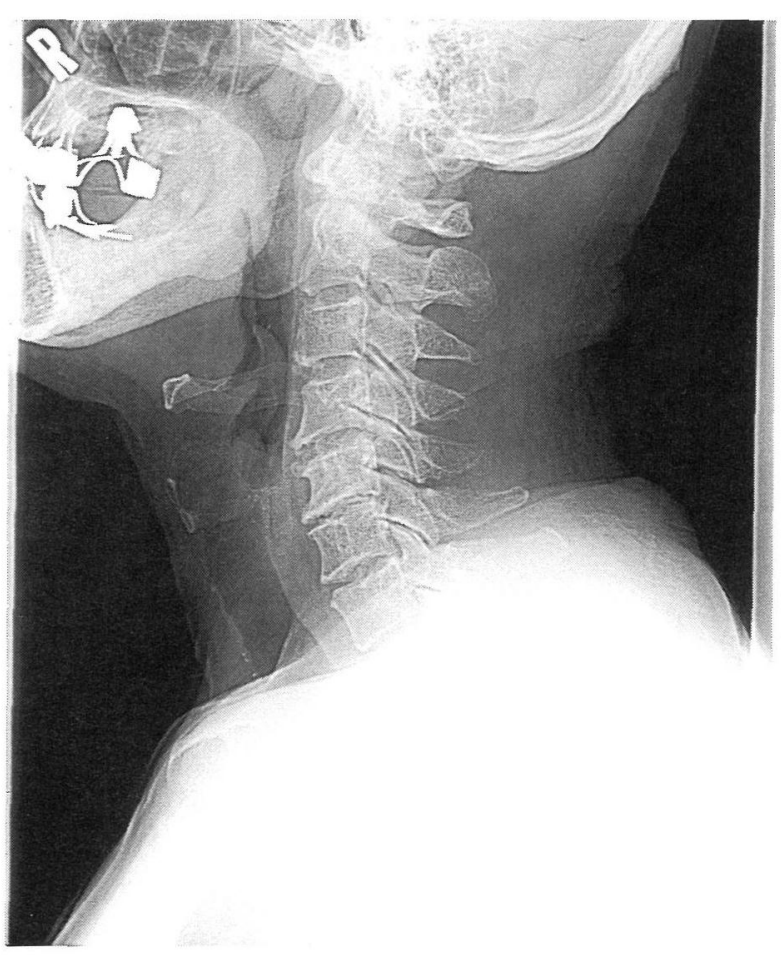

図 7 症例 2 初診時喉頭 $\mathrm{CR}$ 側面像

た。 反回神経麻瘦は認めなかった。喉頭 $\mathrm{CR}$ 側面像を図 7 に示す。喉頭蓋が咽頭後壁側へ倒れ込又, 気道を狭窄 


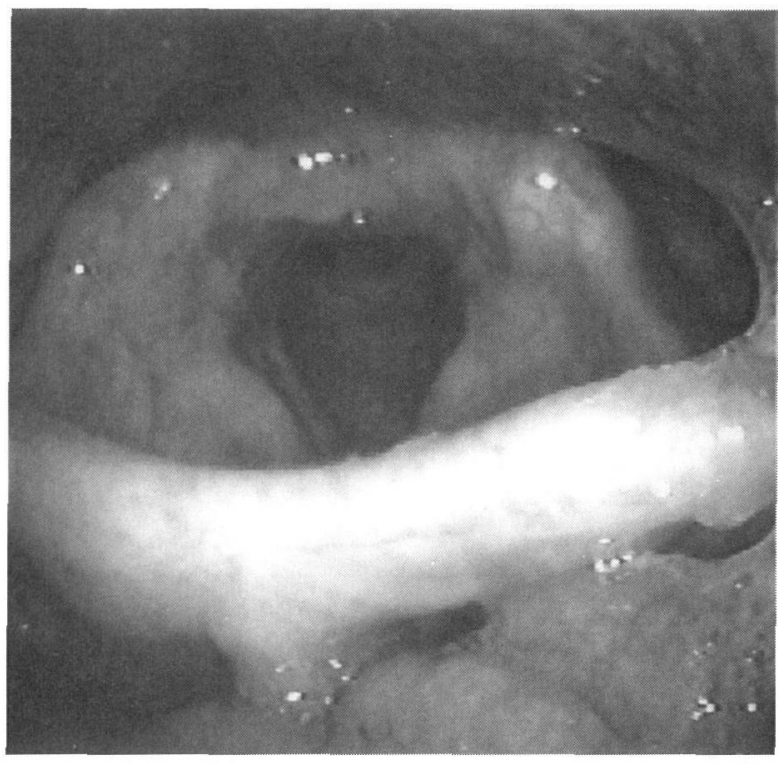

図 8 症例 2 術後 8 カ月の喉頭ファイバースュープ所見

\section{している所見を認めた。}

手術敊よび経過：平成10年 9 月 9 日, 全身麻酔下で喉 頭蓋部分切除術を施行した。症例 1 と同様に, 喉頭展開 の上, 喉頭蓋の先端約 $1 / 3$ をホルミウム YAGレーザー 之箭刀を用いて切除した。本症例では病理組織学的検査 で，喉頭蓋先端部分の軟骨細胞に変性，一部では壤死が みられ，軟骨基質にも変性がみられた。

手術後咽頭違和感はしばらく続いたが，術後 1 年には 軽快した。睡眠時呼吸困難感は手術により軽快した。術 後 8 力月の堠頭ファイバースコープ所見を図 8 亿示す.

\section{考察}

喉頭軟化症は, 乳児の吸気性呼吸障害の原因として比 較的多くみられる1) 5)。一方乳幼児と異なり, 成人になっ てから喉頭蓋の変形や倒れ込及が原因で吸気性呼吸障害 が生じるのは非常にまれである。

成人例は, 吸気性喘鳴, 閉塞型睡眠時無呼吸, 仰臥位 での呼吸困難などの症状を呈するが6，過換気症候群を 呈した症例もある7. 喉頭蓋の倒れ込みは喉頭つァイ バースコープによる観察で診断できるが, 特に仰卧位で の観察が有用である、また, 喉頭蓋の形状や大きさを知 るためには喉頭 CR 側面像が有用であり, 喉頭蓋の切除 範囲を決めるのに参考となる.

成人の㗋頭蓋の倒れ込みの原因としては, 頸部外傷や
頸部腫瘍手術後に喉頭蓋の支持組織が傷害され発症した 症例(6)8, 頭部外傷や脳幹梗塞後, 昏睡からの回復後な ぞ中枢神経系の障害に続発して生じた症例699), 先天的 形成異常が併存した症例10)などの報告があるが，原因 が不明の症例もある7111 13)。中枢神経系の障害に続発し た症例は気管切開後にカニューレ抜去困難で気付かれる ことが多い(6). 原因不明に発症した症例は今回の 2 症例 も含奴 0 歳以上の男性例が多い。間口ら $\left.{ }^{12}\right)$ は老化によ る喉頭の変化も考慮に入れる必要があると考察している. 喉頭蓋軟骨の組織学的所見については，ほとんどの症 例で正常であったと報告されている. 異常所見を認めた 症例には, 軟骨基質の主成分である酸性ムコ多糖類の減 少があり喉頭蓋が脆弱になったと推察されるがその原因 は不明とするもの7), 部分的飞軟骨細胞が消失し繊維組 織で置換され原因不明の軟骨軟化症之診断されたもの などがあった。

われわれの症例では, 頸部外傷や手術の既往はなかっ た。また結核, 梅毒, 急性喉頭蓋炎などの炎症の既往も みられなかった。第1例では喉頭蓋の倒れ込みがみられ るよらになった時期に運動ニューロン疾患(後に筋萎縮 性側索硬化症々診断) 発症して怙り, 何らかの関連が 推測さ礼た。しかし乳児の神経筋疾患の併存例 ${ }^{1}$, 成人 での頭部外傷や脳幹梗塞後, 昏睡からの回復後など中枢 神経系の障害に続発した症例は報告されているが, 筋萎 縮性側索硬化症やその他の運動ニューロン疾患の経過中 に呼吸筋麻痺に先だって, そのような呼吸障害が発症し たといら報告はなく，正確な原因は不明である。第 2 例 では, 病理組織学的に喉頭蓋の先端部分の軟骨細胞と軟 骨基質が変性して扣り，それが軟骨の脆鸧性を引き起こ 乙喉頭蓋の倒れ込久を起こした可能性は考穴られる。し かし過去に炎症性疾患中外傷の既往もなく軟骨細胞と軟 骨基質の変性の原因は不明である.

治療は経過観察のみのものから, 喉頭蓋部分切除を 行ったもの, 誤臙も伴い喉頭全摘を行ったものまで症例 によりさまざをな報告がある。保存的治療のなかには， 加湿のできる鼻咽腔チューブを插入留置することで喉頭 蓋の倒れ込反を防ぎ睡眠時無呼吸が改善した報告8)もあ り, 症状が睡眠時無呼吸の及の場合には有効と思われる が, 睡眠時以外飞も呼吸困難があり経過観察を行っても 改善しない場合には，QOL考考ると喉頭蓋部分切除 が有効之考党る。今回の第 1 例の患者は呼吸困難感が生 じた平成 8 年の時点では呼吸機能は比較的保たれて特り, 
與下構音機能についても食道透視上誤燕を認めず普通食 が摂食可能, 会話も普通に可能な状態だったため, 呼吸 症状の軽減目的で喉頭蓋部分切除を行った. 手術後, 術 前に訴えていた吸気時や睡眠時の呼吸困難は軽快し，ま た手術により鄙下機能が低下することもなかった. 将来 的には呼吸筋麻痺進行に伴う呼吸障害も予想されるが, 平成11年 1 月の他院転院の時点では呼吸困難はみられず, 喉頭蓋部分切除術は有効であったと考兄られる. 第 2 例 も手術により睡眠時呼吸困難感は軽快し, 喉頭蓋部分切 除は有効であった。 また，喉頭蓋の切除範囲については 症例によりさまざまであるが，われわれは㗋頭側面X線 像やファイバースュープの所見を参考に，喉頭蓋先端よ り約 $1 / 3$ を切除し良好な結果を得た。喉頭蓋部分切除後 の誤燕に関しては, 過去の症例での報告はなく，われわ れの症例でも誤與はみられなかった.

喉頭蓋軟骨の切除には従来炭酸ガスレーザーがよく使 用されているが，今回われわれは COHERENT 社製ホ ルミウム YAG レーザー, Versa Pulse Select 22 を用い た。ホルミウム YAG レーザーは発振波形がパルス波で, 蒸散によって組織内に圧力がかかるため，軟部組織のみ ならず他の種類のレーザーでは難しかった軟骨・小規模 な骨などの硬組織の切開も可能である14)。また，水への 吸収率が高く，色素にも影響されず，組織に対する熱侵 襲が浅くかつ一定しているため, 周辺組織の損傷も最小 限にとどめることができる.ファイバースコープ下での 使用も可能であり，耳鼻科領域ではすでに鼻内手術への 応用が報告されているが15)，われわれの症例のように， 出血が多い喉頭蓋や披裂軟骨など喉頭の軟骨組織の切除 にもきわめて有用であった． 2 症例とも，約 1 力月後に は創部はきれいに上皮化し，肉芽の形成もみられなかっ た。

$$
\text { まとめ }
$$

㗋頭蓋の吸気時の倒れ込みによる成人の呼吸障害を 2 例経験したので報告した。

1 例は最終的に進行性筋萎縮性側索硬化症と診断され たが，喉頭蓋の倒れ込みと同症との関連は不明であり正 確な原因は不明であった。他の 1 例は病理組織学的検査 で喉頭蓋の軟骨細胞に変性傾向がみられ，喉頭蓋軟骨の 脆弱性が示唆されたが，やはり変性の原因は不明であっ た.これら 2 例とも，喉頭蓋部分切除を施行し，呼吸障 害は改善した。また喉頭蓋軟骨の部分切除にはホルミウ
ム YAG レーザーが有用であった。

\section{参考文献}

1) Solomons NB and J. Prescott CA : Laryngomalacia ; a review and the surgical management for severe cases. Int J Pediatr Otorhinolaryngol $13:$ 31 39, 1987.

2 ) Ronald WL, Dudley JW, Cynthia S, et al : Laryngomalacia ; a review and case report of surgical treatment with resolution of pectus excavatum. Arch Otolaryngol 110 : $546 \sim 551,1984$.

3 ) Lauren DH and Raymond JK : Surgical management of severe laryngomalacia. Laryngoscope 99:136 142, 1989.

4 ) 山形和彦, 野本俊司, 兵頭政光, 他 : 手術治療の奏効した 喉頭軟化症の 1 例. 日気食会報 $44: 296 \sim 300,1993$.

5 ) Judson RB and Kenneth G : Congenital laryngeal stridor (Laryngomalacia) etiologic factors and associated disorders. Ann Otol Rhinol Laryngol 93 : 430 437, 1984.

6 ) Woo P : Acquired laryngomalacia ; epiglottis prolapse as a cause of airway obstruction. Ann Otol Rhinol Laryngol $101: 314 \sim 320,1992$.

7 ）田中藤信, 塚崎尚紀, 中島成人, 他 : Flaccid epiglottis に より過換気症候群を呈した一例. 耳鼻 $42: 354 \sim 357,1996$.

8 ) Chetty KG, Kadifa F, Berry RB, et al : Acquired laryngomalacia as a cause of obstructive sleep apnea. Chest $106: 1898 \sim 1899,1994$.

9) Andersen D, Alving J, Lildholdt T, et al : Obstructive sleep apnea initiated by a lax epiglottis. Chest $91: 621$ $\sim 623,1987$.

10) Temler J, Hast M, Thomas JR, et al : Congenital laryngeal stridor secondary to flaccid epiglottis, anormalous accessory cartilages and redundant aryepiglottic folds. Laryngoscope $91: 394 \sim 397,1981$.

11）河合 敏, 佃 守, 稲葉 鋭, 他: 原因不明の成人の喉 頭蓋軟骨軟弱症の 1 例. 日気食会報 $50: 414 \sim 419,1999$.

12）間口四郎，千田英二, 熊谷雅彦, 他 : “Flaccid Epiglottis” により呼吸障害を呈した 1 例. 耳鼻 $36: 1219 \sim 1223,1990$.

13) Harries PG and Randall CJ : Adult floppy epiglottis; a simple surgical remedy. J Laryngol Otol $109: 871 \sim 872$, 1995.

14）中之坊学, 田部哲也, 松永 毅, 他 : ホルミウム・ヤグレー ザー照射の生体組織に対する影響について。.日レーザー医 会誌 $17: 11 \sim 18,1996$.

15）池田勝久, 大島猛史, 鈴木秀明, 他 : Ho : YAG レーザー と内視鏡下鼻内手術. 耳鼻臨床 $88: 1427 \sim 1431,1995$.

\footnotetext{
原稿受付：平成12年 3 月 13 日

原稿採択 : 平成 12 年 3 月 29 日

別刷請求先 : 田中明子

干606-8507 京都市左京区聖護院川原町54

京都大学医学部耳鼻咽喉科学教室
} 